\title{
NILAI MPN (Most Probable Number) DAN DETEKSI BAKTERI Esherichia PADA MINUMAN ES JERUK PERAS di KOTA PONTIANAK
}

\author{
Ratna $^{1}$, Rahmawati $^{1}$, Mukarlina ${ }^{1}$ \\ ${ }^{1}$ ProgramStudiBiologi, FakultasMIPA, UniversitasTanjungpura, \\ JL. Prof. Dr. H. HadariNawawi, Pontianak, 78124, \\ email korespondensi: ratnaelislamih@gmail.com
}

\begin{abstract}
Iced squeezed orange drinks is one one of processed drinks that made from orange. Good drinking water should not contain pathogenic bacteria or organisms that may harm human health. Coliform is one of bacteria that may cause disease in humans and being used as indicator bacteria of pathogenic bacteria. This research was aimed to know the MPN value number of coliform bacteria and to identify the bacterial presence of genus Escherichia in iced squeezed orange drinks sold in Pontianak City. The sampling used random sampling method. MPN method was used in order to know the number of coliform in iced squeezed orange drinks in Pontianak City. MPN test result obtained the lowest index value of MPN/mL was $0,14 / \mathrm{mL}$ in sample in subdistrict Pontianak City and the highest index value in four subdistricts in Pontianak City was MPN $/ \mathrm{mL}>24,00 / \mathrm{mL}$. It was showed that five samples exceed normal limits in accordance with SNI standardsSNI 01-3839-1995 based on Permenkes No 492/MENKES/per/IV/2010. Identification result showed the bacterial genus of coliform obtained was member of genus Escherichia.
\end{abstract}

Keywords: Iced squeezed orange drinks, Coliform, MPN, Escherichia

\section{PENDAHULUAN}

Makanan dan minuman merupakan subtansi yang sangat esensial bagi pertumbuhan dan perkembangan manusia. Kandungan zat-zat dalam makanan dan minuman akan sangat berpengaruh terhadap keseimbangan fungsi fisiologis tubuh sehingga makanan dan minuman yang dikonsumsi harus memenuhi standar kesehatan. Menurut Anantajati (2011), makanan dan minuman tidak boleh mengandung atau melebihi batas maksimum cemaran mikroba karena dapat menimbulkan permasalahan kesehatan bagi yang mengkonsumsinya terutama yang mengandung bakteri patogen. Bakteri ini dapat menyebabkan penyakit di antaranya diare, kolera, disentri, tifus, dan penyakit lainnya.

Bakteri golonganColiform adalah kelompok bakteri gram negatif berbentuk batang yang menghasilkan gas jika ditumbuhkan dalam medium laktosa. Bakteri golongan Coliform merupakan indikator kontaminasi lingkungan atau sanitasi yang kurang baik sedangkan Escherichia sebagai indikator kontaminasi yang berasal dari tinja manusia dan hewan berdarah panas (Tururaja \& Mogea, 2010). Bakteri golongancoliform menyebabkan demam dan diare. Jumlah dan jenis bakteri bervariasi dan berbeda sesuai dengan tempat dan kondisi yang mempengaruhinya. Batas maksimum cemaran mikroba dalam minuman adalah 0/100mL. Standar tentang batas maksimum cemaran mikroba ini digunakan sebagai parameter terhadap hasil pemeriksaan di laboratorium (SNI,2009).

Minuman es jeruk peras merupakan salah satu jenis minuman jajanan yang saat ini banyak dikonsumsi oleh masyarakat luas.Minuman es jeruk peras cukup digemari di kalangan anak-anak sampai orang tua karena memiliki rasa yang asam,manis dan menyegarkan. Pedagang minuman es jeruk peras di Kota Pontianak pada umumnya berjualan di pinggir jalan menggunakan gerobak dan menggunakan alat khusus untuk memeras jeruk. Es jeruk peras tersebut disajikan secara konvensional dalam gelas plastik. Peralatan, peyimpanan, dan pengelolahan minuman es jeruk peras dapat menjadi penyebab kontaminasi mikroba patogen. Penelitian Prajna et al. (2016) menunjukkan bahwa dari kualitas mikrobiologis es jeruk kemasan MS (Memenuhi Syarat) adalah jika Coliform < 3 dan tidak tercemar Escherichia coli (Coliform dan Escherichia coli memenuhi syarat). Sehingga jumlah sampel es jeruk memenuhi syarat (MS) sebanyak $15,4 \%$ atau 6 sampel es jeruk 
kemasan, dan sebanyak 33 sampel tidak memenuhi syarat (TMS).

Es jeruk peras di Kota Pontianak diduga dapat terkontaminasi oleh bakteri Coliform, disebabkan oleh kurangnya kebersihan dalam pengolahan es jeruk peras. Berdasarkan uraian di atas, perlu dilakukan penelitian tentang bakteri golongan Coliform pada minuman es jeruk peras di Kota Pontianak.

\section{BAHAN DAN METODE}

Waktu dan Tempat Penelitian

Penelitian ini dilaksanakan dari bulan Maret hingga Mei 2019. Pengambilan sampel dilakukan di Kota Pontianak. Identifikasi dan analisis data dilakukan di Laboratorium Mikrobiologi, Jurusan Biologi Fakultas Matematika dan Ilmu Pengetahuan Alam, Universitas TanjungPura Pontianak, Kalimantan Barat.

\section{Alat dan Bahan \\ Alat-alat yang digunakan dalam penelitian ini adalah bunsen, cawan petri, cover glass, cooling box, cool pack, gelas beker, erlenmeyer, gelas objek, gelas ukur, hot plate, incubator bakteri, jarum ose, kapas, kertas label, kertas pembungkus,latex, magnetic stirrer, masker, pipet tetes, pipet ukur, pinset, plastik pembungkus, rak tabung, spatula, spuit, sheaker, tabung durham, tabung reaksi, timbangan analitik dan vortex.}

Bahan-bahan yang digunakan dalam penelitian ini yaitu sampel es jeruk peras tanpa es batu, jeruk peras dengan es batu dan air gula, alumunium foil, alkohol 70\%, akuades, media Brilliant Green Lactose Borth (BGLB), media Eosin Metyhlen Blue Agar (EMBA), media LactoseBroth (LB).

\section{Prosedur Kerja \\ Pengambilan Sampel}

Sampel es jeruk peras diambil pada lima kecamatan di Kota Pontianak. Masing-masing sampel es jeruk peras diambil, jeruk peras murni, es batu, dan air gula sebanyak 3 gelas dari masingmasing gerobak pedagang. Sampel kemudian dimasukkan ke dalam plastik dan cooling box, kemudian dibawa ke Laboratorium Mikrobiologi, Jurusan Biologi, Fakultas Matematika dan Ilmu Pengetahuan Alam, Universitas Tanjungpura, Pontianak.

\section{Isolasi Bakteri GolonganColiform \\ Pengenceran}

Sampel yang telah diambil dari masing-masing gerobak penjual, dimasukkan sebanyak $1 \mathrm{~mL}$ ke dalam tabung reaksi yang berisikan $9 \mathrm{ml}$ akuades sebagai pengenceran $10^{-1}$, kemudian dihomogenkan menggunakan vortex, selanjutnya dibuat pengenceran $10^{-2}$ dan $10^{-3}$ dengan cara yang sama (Waluyo,2008).

Uji Angka Paling Mungkin (APM) / Most Probable Number (MPN)

Pengujian ini dilakukan dengan metode MPN melalui dua tahapan yaitu Uji Penduga (Presumtif Test) dan Uji Penegas (Confirmative Test) (Nugroho, 2006):

\section{Uji Penduga (Presumtif Test)}

Sampel hasil pengenceran $10^{-1}, 10^{-2}$ dan $10^{-3}$ diambil sebanyak $1 \mathrm{ml}$ dan masing-masing dimasukkan ke dalam 3 tabung yang berisi $9 \mathrm{ml}$ media Lactose Broth (LB). Selanjutnya setiap tabung yang berisi sampel diinkubasi selama 24-48 jam dengan suhu $37^{\circ} \mathrm{C}$. Setelah diinkubasi jumlah tabung yang terdapat gas diamati dan dicatat kemudian diuji dengan uji penegas.

\section{Uji Penegas (Confirmative Test)}

Sampel didalam tabung diambil sebanyak 1 ose, dan dipindahkan ke dalam tabung yang berisi $9 \mathrm{ml}$ media Brilliant Green Lactose Broth(BGLB) dan dilengkapi dengan tabung durham terbalik. Seluruh tabung diinkubasi pada suhu $37{ }^{\circ} \mathrm{C}$ selama 24-48 jam. Uji dinyatakan positif jika terbentuk gas dan gelembung dalam tabung durham. Jumlah tabung yang terbentuk gas pada uji penegas dan disesuaikan dengan tabel Most Probable Number (MPN) (SNI 7388:2009). Jumlah angka yang didapatkan pada tabel MPN menunjukan jumlah bakteri golongancoliformdalam tiap $\mathrm{g} / \mathrm{ml}$ sampel yang diujikan.

\section{Uji Pelengkap (Completed Test)}

Suspensi sampel dari tabung yang menunjukan hasil positif dalam uji konfirmasi selanjutnya diambil sebanyak 1 jarum ose dan diinokulasikan kedalam cawan petri yang berisikan media Eosin Methylene Blue Agar (EMBA), kemudian diinkubasikan pada suhu $37^{\circ} \mathrm{C}$ selama $24-48$ jam. Koloni yang berwarnahijau metalik dan bintik biru kehijauan merupakan koloni bakteri anggota genus Escherichia (Cappucino \& Sherman, 2012). 


\section{Analisis dan Penyajian Data}

Penelitian ini bersifat observatif dan deskriptif. Data yang diperoleh didokumentasikan dan dideskripikan berdasarkan hasil pengujian nilai MPN dan deteksi bakteri anggota genus Esherichia pada media EMBA di laboratorium serta pengamatan faktor kebersihan lingkungan.

\section{HASIL}

Pengujian Bakteri Golongan Coliform Dengan Metode MPN pada Es Jeruk di Kota Pontianak

Berdasarkan hasil uji MPN yang diperoleh menunjukan bahwa semua sampel uji positif mengandung bakteri golongan Coliform. Dari tiga puluh sampel minuman es jeruk peras yang telah diuji, sampel es jeruk peras dari Pontianak Kota yang memiliki nilai indeks $\mathrm{MPN} / \mathrm{mL}$ terendah yakni 0,14 (MPN/mL), Berdasarkan hasil yang didapat, seluruh sampel menunjukkan hasil TMS (tidak memenuhi syarat). Menurut Peraturan MenteriKesehatan berdasarkan No. 492/MENKES/Per/IV/2010 tentang persyaratan kualitas air minum.

Tabel 1 Nilai MPN Bakteri Coliform pada Jeruk Peras Murni

\begin{tabular}{cccc}
$\begin{array}{c}\text { Tabel 1 Nilai MPN Bakteri Coliform pada Jeruk Peras Murni } \\
\begin{array}{c}\text { Tempat Pengambilan } \\
\text { Sampel Wilayah Pontianak } \\
\text { (Pedagang) }\end{array}\end{array} \begin{array}{c}\text { Coliform } \\
\text { (MPN/mL) }\end{array}$ & $\begin{array}{c}\text { Standar } \\
\text { Coliform } \\
\text { (MPN/mL) }\end{array}$ & Keterangan \\
\hline Kota 1 & 0,14 & $0 / 100 \mathrm{~mL}$ & Tidak Memenuhi Syarat \\
Barat 1 & $>24,00$ & $0 / 100 \mathrm{~mL}$ & Tidak Memenuhi Syarat \\
Selatan 1 & $>24,00$ & $0 / 100 \mathrm{~mL}$ & Tidak Memenuhi Syarat \\
Timur 1 & $>24,00$ & $0 / 100 \mathrm{~mL}$ & Tidak Memenuhi Syarat \\
Utara 1 & $>24,00$ & $0 / 100 \mathrm{Ml}$ & Tidak Memenuhi Syarat \\
Kota 2 & $>24,00$ & $0 / 100 \mathrm{~mL}$ & Tidak Memenuhi Syarat \\
Barat 2 & $>24,00$ & $0 / 100 \mathrm{~mL}$ & Tidak Memenuhi Syarat \\
Selatan 2 & $>24,00$ & $0 / 100 \mathrm{~mL}$ & Tidak Memenuhi Syarat \\
Timur 2 & $>24,00$ & $0 / 100 \mathrm{~mL}$ & Tidak Memenuhi Syarat \\
Utara 2 & $>24,00$ & $0 / 100 \mathrm{~mL}$ & Tidak Memenuhi Syarat \\
\hline
\end{tabular}

Tabel 2 Nilai MPN Bakteri Coliform pada Es Batu

\begin{tabular}{cccc}
\hline $\begin{array}{c}\text { Tempat Pengambilan } \\
\text { Sampel Wilayah } \\
\text { Pontianak (Pedagang) }\end{array}$ & $\begin{array}{c}\text { Coliform } \\
(\mathrm{MPN} / \mathrm{mL})\end{array}$ & $\begin{array}{c}\text { Standar Coliform } \\
(\mathrm{MPN} / \mathrm{mL})\end{array}$ & Keterangan \\
\hline Kota 1 & 0,14 & $0 / 100 \mathrm{~mL}$ & Tidak Memenuhi Syarat \\
Barat 1 & $>24,00$ & $0 / 100 \mathrm{~mL}$ & Tidak Memenuhi Syarat \\
Selatan 1 & $>24,00$ & $0 / 100 \mathrm{~mL}$ & Tidak Memenuhi Syarat \\
Timur 1 & $>24,00$ & $0 / 100 \mathrm{~mL}$ & Tidak Memenuhi Syarat \\
Utara 1 & $>24,00$ & $0 / 100 \mathrm{Ml}$ & Tidak Memenuhi Syarat \\
Kota 2 & 0,14 & $0 / 100 \mathrm{~mL}$ & Tidak Memenuhi Syarat \\
Barat 2 & $>24,00$ & $0 / 100 \mathrm{~mL}$ & Tidak Memenuhi Syarat \\
Selatan 2 & $>24,00$ & $0 / 100 \mathrm{~mL}$ & Tidak Memenuhi Syarat \\
Timur 2 & $>24,00$ & $0 / 100 \mathrm{~mL}$ & Tidak Memenuhi Syarat \\
Utara 2 & $>24,00$ & $0 / 100 \mathrm{~mL}$ & Tidak Memenuhi Syarat \\
\hline
\end{tabular}


Tabel 3 Nilai MPN Bakteri Coliform pada Air Gula

\begin{tabular}{cccc}
\hline $\begin{array}{c}\text { Tempat Pengambilan } \\
\text { Sampel Wilayah } \\
\text { Pontianak (Pedagang) }\end{array}$ & $\begin{array}{c}\text { Coliform } \\
(\mathrm{MPN} / \mathrm{mL})\end{array}$ & $\begin{array}{c}\text { Standar Coliform } \\
(\mathrm{MPN} / \mathrm{mL})\end{array}$ & Keterangan \\
\hline Kota 1 & 0.14 & $0 / 100 \mathrm{~mL}$ & Tidak Memenuhi Syarat \\
Barat 1 & $>24,00$ & $0 / 100 \mathrm{~mL}$ & Tidak Memenuhi Syarat \\
Selatan 1 & $>24,00$ & $0 / 100 \mathrm{~mL}$ & Tidak Memenuhi Syarat \\
Timur 1 & $>24,00$ & $0 / 100 \mathrm{~mL}$ & Tidak Memenuhi Syarat \\
Utara 1 & $>24,00$ & $0 / 100 \mathrm{Ml}$ & Tidak Memenuhi Syarat \\
Kota 2 & $>24,00$ & $0 / 100 \mathrm{~mL}$ & Tidak Memenuhi Syarat \\
Barat 2 & $>24,00$ & $0 / 100 \mathrm{~mL}$ & Tidak Memenuhi Syarat \\
Selatan 2 & $>24,00$ & $0 / 100 \mathrm{~mL}$ & Tidak Memenuhi Syarat \\
Timur 2 & $>24,00$ & $0 / 100 \mathrm{~mL}$ & Tidak Memenuhi Syarat \\
Utara 2 & $>24,00$ & $0 / 100 \mathrm{Ml}$ & Tidak Memenuhi Syarat \\
\hline
\end{tabular}

\section{Hasil Deteksi Bakteri Anggota Genus Esherichia pada Es Jeruk Peras di Kota Pontianak}

Berdasarkan hasil deteksi bakteri anggota genus Esherichia dari es jeruk peras di sepuluh penjual es jeruk peras yaitu Pontianak Kota, Pontianak Selatan, Pontianak Timur, Pontianak Barat, Pontianak Utara, diperoleh tiga puluh isolat yaitu isolat dengan kode R1, R2, R3, R4, sampai dengan R30. Tiap isolat memiliki karakteristik morfologis yang sama (Tabel 4 ).

Tabel 4 Karakter Morfologis Isolat Bakteri Coliform Pada Es Jeruk Peras yang di peroleh di Kota Pontianak

\begin{tabular}{|c|c|c|c|c|}
\hline Kode Isolat & Bentuk & Warna & Tepian & Elevasi \\
\hline $\mathrm{R} 1$ & Bulat & Hijau Metalik & Rata & Rata \\
\hline $\mathrm{R} 2$ & Bulat & Hijau Metalik & Rata & Rata \\
\hline R3 & Bulat & Hijau Metalik & Rata & Rata \\
\hline $\mathrm{R} 4$ & Bulat & Hijau Metalik & Rata & Rata \\
\hline R5 & Bulat & Hijau Metalik & Rata & Rata \\
\hline R6 & Bulat & Hijau Metalik & Rata & Rata \\
\hline R7 & Bulat & Hijau Metalik & Rata & Rata \\
\hline R8 & Bulat & Hijau Metalik & Rata & Rata \\
\hline R9 & Bulat & Hijau Metalik & Rata & Rata \\
\hline $\mathrm{R} 10$ & Bulat & Hijau Metalik & Rata & Rata \\
\hline R11 & Bulat & Hijau Metalik & Rata & Rata \\
\hline $\mathrm{R} 12$ & Bulat & Hijau Metalik & Rata & Rata \\
\hline $\mathrm{R} 13$ & Bulat & Hijau Metalik & Rata & Rata \\
\hline $\mathrm{R} 14$ & Bulat & Hijau Metalik & Rata & Rata \\
\hline $\mathrm{R} 15$ & Bulat & Hijau Metalik & Rata & Rata \\
\hline R16 & Bulat & Hijau Metalik & Rata & Rata \\
\hline $\mathrm{R} 17$ & Bulat & Hijau Metalik & Rata & Rata \\
\hline $\mathrm{R} 18$ & Bulat & Hijau Metalik & Rata & Rata \\
\hline R19 & Bulat & Hijau Metalik & Rata & Rata \\
\hline R20 & Bulat & Hijau Metalik & Rata & Rata \\
\hline $\mathrm{R} 21$ & Bulat & Hijau Metalik & Rata & Rata \\
\hline $\mathrm{R} 22$ & Bulat & Hijau Metalik & Rata & Rata \\
\hline $\mathrm{R} 23$ & Bulat & Hijau Metalik & Rata & Rata \\
\hline $\mathrm{R} 24$ & Bulat & Hijau Metalik & Rata & Rata \\
\hline $\mathrm{R} 25$ & Bulat & Hijau Metalik & Rata & Rata \\
\hline R26 & Bulat & Hijau Metalik & Rata & Rata \\
\hline $\mathrm{R} 27$ & Bulat & Hijau Metalik & Rata & Rata \\
\hline $\mathrm{R} 28$ & Bulat & Hijau Metalik & Rata & Rata \\
\hline R29 & Bulat & Hijau Metalik & Rata & Rata \\
\hline $\mathrm{R} 30$ & Bulat & Hijau Metalik & Rata & Rata \\
\hline
\end{tabular}


Hasil pengamatan faktor kebersihan lingkungan Sanitasi berdasarkan hasil obervasi terhadap pedagang Es Jeruk Peras di Kota Pontianak

Berdasarkan hasil lembar observasi yang saya lakukan di 10 pedagang es jeruk peras yaitu dapat dilihat bahwa pada umumnya pedagang tidak mencuci tangan sebelum membuat minuman, tidak memakai sarung tangan dan tidak memakai masker serta tidak menggunakan celemek dan hanya sekitar $70 \%$ yang mengikat rambut rambutnya (Gambar 2).
Pada umumnya pedagang juga kurang memperhatikan bahan dan proses pengolahan bahan yang digunakan, terutama jeruk tidak tertutup dan tidak di cuci dahulu sebelum digunakan, serta air yang digunakan untuk membuat air gula tidak di masak oleh sebagian pedagang 20\% (Gambar 4). Lokasi penjualan es jeruk peras yang berada di tepi jalan jugadapat menyebabkan potensi terjadi kontaminasi mikroba pada minuman es jeruk peras (Gambar 5).

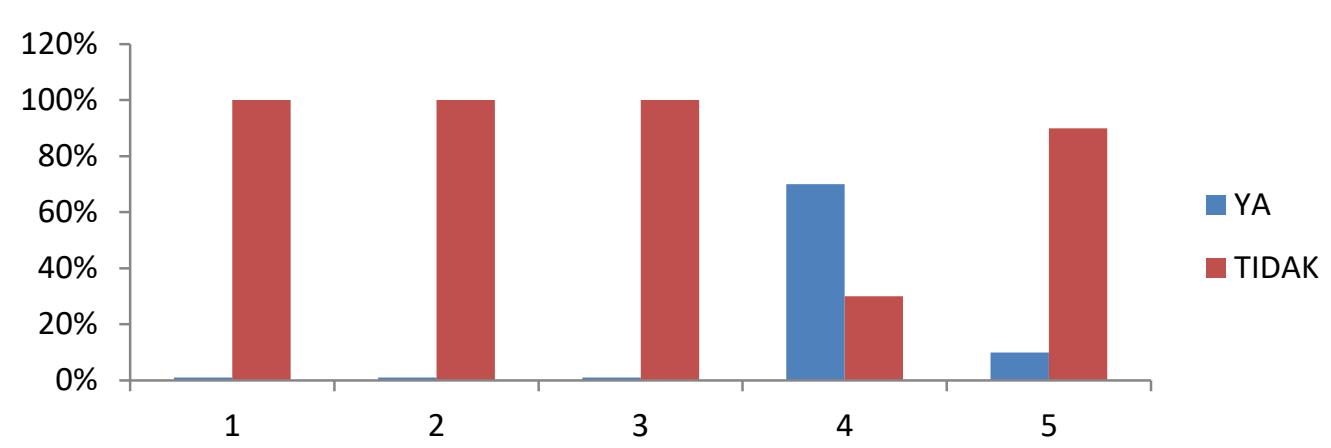

Gambar 2 Hasil Observasi Terhadaap Faktor Sanitasi Pedagang pada Penjual Es Jeruk Peras di Kota Pontianak

Ket : $\quad$ 1. Mencuci tangan setiap kali membuat minuman 2. Memakai sarung tangan

3. Memakai masker4. Mengikat rambut 5. Memakai celemek

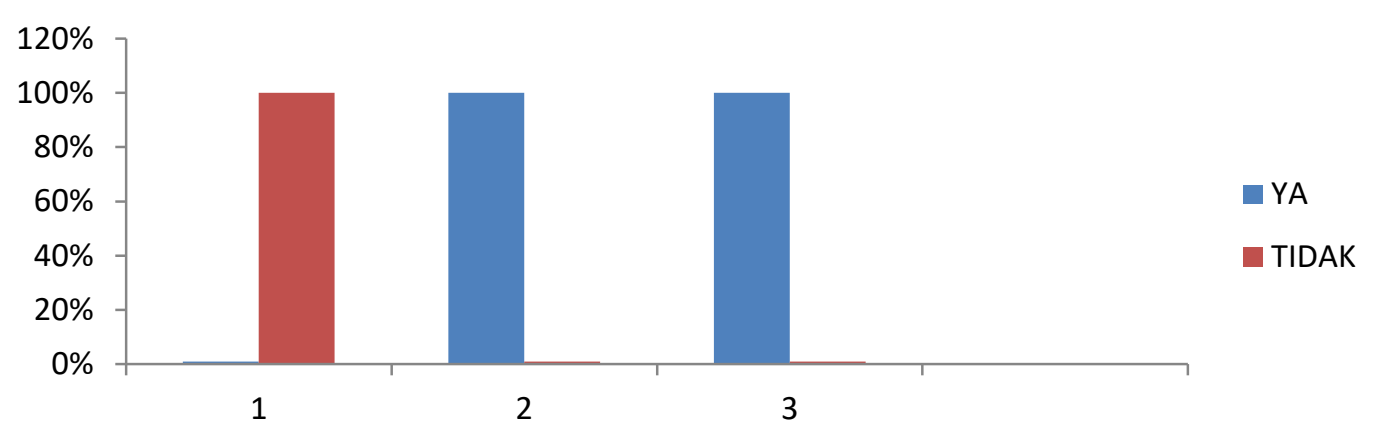

Gambar 3 Hasil Observasi Terhadap Faktor Sanitasi Peralatan pada Penjual Es Jeruk Peras di Kota Pontianak

Ket : $\quad$ 1. Mencuci peralatan sebelum dan sesudah digunakan

2. Kondisi alat pemeras jeruk yang bersih / kotor

3. Kondisi meja penyajian yang bersih / kotor

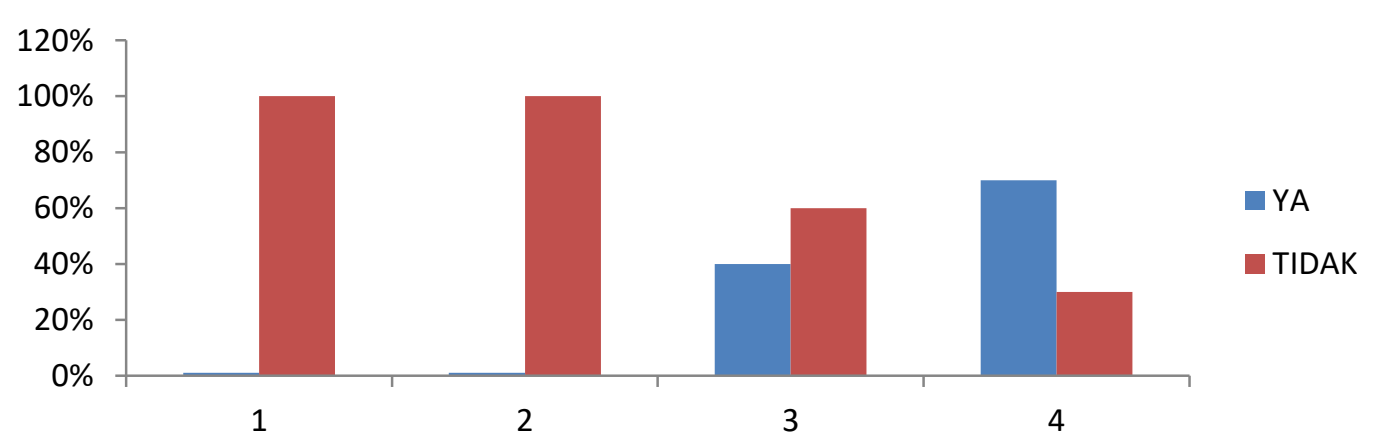


Gambar 4 Hasil Observasi Terhadap Faktor Sanitasi Bahan dan Pengolahan pada Penjual Es Jeruk Peras di Kota Pontianak

Ket : $\quad$ 1. Jeruk yang diolah dimasukan kedalam wadah tertutup

2. Jeruk yang digunakan di cuci terlebih dahulu

3. Air gula yang digunakan adalah air hujan atau air gallon

4. Air gula dimasak atau tidak

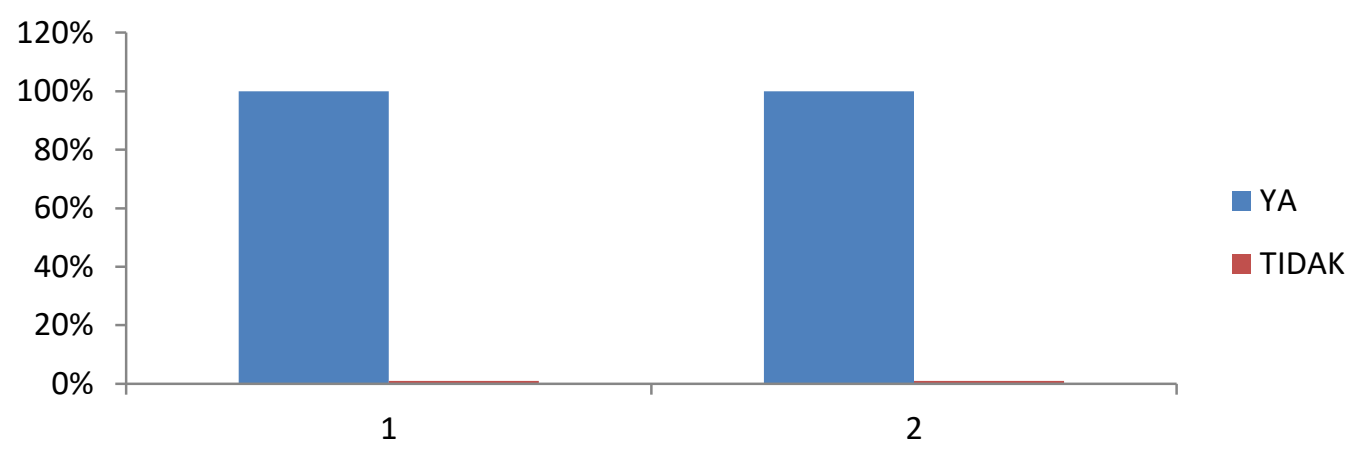

Gambar 5 Hasil Observasi Terhadap Faktor Sanitasi Kebersihan Lingkungan pada Penjual Es Jeruk Peras di Kota Pontianak

Ket : $\quad$ 1. Kondisi gerobak

2. Lokasi penjualan berada ditepi jalan

\section{Pembahasan}

Pengujian bakteri Coliform dengan metode MPN Pemeriksaan bakteri Coliform dengan metode MPN, dilakukan melalui uji penduga (presumtive test) dan uji penegas (confirmative test). Media yang digunakan untuk uji praduga adalah Lactose Broth (LB). Media ini mengandung laktosa yang yang menyediakan sumber karbohidrat yang dapat difermentasi olehColiform. Hasil positif pada uji ini dapat dilihat dari pembentukan gas pada tabung durham. Uji konfirmasi menggunakan media BGLB yang dapat menghambat pertumbuhan bakteri yang tidak hidup dalam saluran pencernaan manusia dan mengahambat pertumbuhan bakteri gram positif dan negatif selain Coliform.

Berdasarkan penelitian yang telah dilakukan pada 30 sampel minuman es jeruk peras yang dijual di beberapa lokasi, diperoleh hasil pada uji MPN bahwa ke lima sampel telah melebihi batas normal tentang syarat-syarat dan pengawasan kualitas air minum, berdasarkan penelitian mikrobiologi terhadap anggota spesies Escherichia coli adalah 0/100 mL. Hal ini diduga di pengaruhi oleh faktor sanitasi.

Berdasarkan hasil observasi menunjukan bahwa lima tempat penjualan es jeruk peras melakukan proses sanitasi yang kurang baik seperti pada penanganan dan pengolah sampel, penggunaan peralatan yang tidak bersih karena dicuci menggunakan air parit dan pada air gula campuran es jeruk peras yang sudah direbus menggunakan air hujan dan air galon yang sebagian tidak dimasak terlebih dahulu.

Soemirat (2002) menyatakan bahwa sumber air hujan merupakan sumber air yang terlindung, kualitas air hujan tergantung pada kualitas udara yang dilaluinya sewaktu turun kembali ke permukaan bumi. Menurut Rezavie (2009), kontaminasi pada air minum biasa diakibatkan oleh terkontaminasinya air baku, tangan, peralatan dan pakaian pekerja serta higenitas buruk. Air pencucian peralatan yang menggunakan air parit juga dapat mempengaruhi kontaminasi bakteri Coliform.

Kontaminasi mikroba dapat pula disebabkan karena jarak lokasi penjualan minuman es jeruk peras ini dengan jalan terlalu dekat sehingga kemungkinan terkontaminasi bakteri yang berasal dari partikel debu di udara. Menurut Laluraa \& Hanny (2014) bahwa penjual yang menggunakan peralatan yang tidak bersih dan berulang-ulang serta hanya diletakan di ruang terbuka dapat memacu terjadinya kontaminasi mikroba. Peryataan ini didukung oleh Faridz (2007) yang menyatakan bahwa pada peralatan yang berasal dari sisa-sisa makanan atau minuman yang masih menempel dan debu dari polusi udara akibat penyimpanan peralatan pada ruang terbuka. 
Penyebab lain kontaminasi bakteri dapat terjadi karena penjual tidak menggunakan peralatan yang sesuai dengan prinsif sanitasi saat melayani konsumen maupun saat melakukan proses pembuatan minuman es jeruk peras. Prinsip sanitasi yang harus diterapkan oleh penjual yaitu menggunakan masker, baju khusus yang ringan dan menyerap keringat atau dapat menggunakan celemek lalu menggunakan sarung tangan serta mengikat rambut. Hal ini untuk menghindari terjadinya kontaminasi pada saat proses pembuatan minuman.

Hasil observasi terhadap sampel penjual es jeruk peras dijual di Kota Pontianak diperoleh dari kebanyakan sumber es batu yang digunakan bukan buatan sendiri. Es batu merupakan produk pangan yang sudah sangat dikenal oleh kalangan masyarakat yang secara umum dianggap aman untuk dikonsumsi. Es batu bahkan digunakan sebagai bahan yang dapat mempertahankan memperpanjang kesegaran suatu produk minuman. Timbulnya penyakit yang berkaitan dengan konsumsi es batu dapat dihubungkan dengan kurang diperhatikannya faktor kebersihan dan sanitasi penanganan es batu, misalnya air yang digunakan dalam pembuatan es batu menggunakan air mentah (Slamet, 2009).

\section{Deteksi Bakteri Esherichia coli dari Es Jeruk Peras}

Berdasarkan hasil uji pelengkap menunjukan bahwa sampel positif menggandung bakteri golongan Coliform dan merupakan bakteri anggota genusEsherichia. Uji pelengkap ini dapat digunakan untuk membedakan bakteri fekal dan non fekal. Bakteri golongan fekal dapat tumbuh pada suhu $35^{\circ} \mathrm{C}-37^{\circ} \mathrm{C}$ atau lebih, sedangkan bakteri non fekal tidak dapat tumbuh pada suhu tersebut tetapi dapat tumbuh pada suhu $37^{\circ} \mathrm{C}$ (Widyanti,2004). Isolat bakteri anggota spesies E.coli yang diamati diduga termasuk golongan fekal dikarenakan dapat tumbuh pada suhu inkubasi yaitu $35^{\circ} \mathrm{C}-37^{\circ} \mathrm{C}$.

Koloni anggota genus Esherichia pada media EMBA menunjukkan pertumbuhan yang baik dengan warna koloni hijau metalik. EMBA adalah media selektif dan media diferensial. Media ini mengandung Eosin dan metilen biru, yang menghambat pertumbuhan bakteri Gram positif, maka media ini dipilih untuk bakteri Gram negatif. EMBA juga mengandung karbohidrat laktosa, dengan adanya karbohidrat laktosa bakteri Gram negatif terdiferensiasi berdasarkan pada kemampuan mereka untuk memfermentasi laktosa. Warna media sebelum pemupukan bakteri berwarna merah keunguan. Perubahan warna hijau metalik pada media EMBA karena Escherichia coli dapat memfermentasi laktosa yang mengakibatkan peningkatan kadar asam dalam media. Kadar asam yang tinggi dapat mengendapkan methylenblue dalam media EMBA. Hasil pewarnaan gram pada 10 sampel minuman es jeruk peras yang diuji memperlihatan bahwa bakteri yang berbentuk basil pendek berwarna merah muda. Hal ini menunjukan bahwa bakteri tersebut merupakan bakteri gram negatif. Prinsip pewarnaan gram adalah tergantung komposisi dinding sel. Sel gram positif mempunyai dinding dengan lapisan peptidoglikan yang tebal, sedangkan gram negatif memiliki dinding peptidoglikan yang lebih tipis dengan lapisan luar lipid. Bakteri yang tetap berwarna ungu dengan pewarnaan oleh Kristal violet disebut gram positif, sedangkan bakteri gram negatife menjadi berwarna merah muda (Supardi, 1999). Hal ini sesuai dengan karakter anggota genus Esherichia, dengan demikian diduga salah satu bakteri golongan Coliform yang mengkotaminasi es jeruk peras di Kota Pontianak adalah anggota genus Esherichia.

\section{DAFTAR PUSTAKA}

Anantajati, P, 2011, Hubungan Pengetahuan dan Praktik Higiene Perorangan Dengan Angka Kuman dan Bakteri Patogen Pada Penjamah Makanan di Katering PT. PIM Kalimantan Timur, Fakultas Kedokteran, Program Studi Pasca Sarjana Ilmu Kesehatan Masyarakat, Universitas Gajah Mada, Yogyakarta

Cappuccino, GJ \& Sherman, N, 2014, Microbiology; ALaboratory Manual, 10th ed, Pearson Education, USA

Faridz, R, Hafiluddin \& M, Anshari, 2007, 'Analisis Jumlah Bakteri dan Keberadaan Escherichia coli pada Pengelolahan Ikan Teri Nasi PT. Kelola Mina Laut Unit Sumenep', Skripsi, Universitas Trunojoyo, Madura

Laluraa LFH, Lohoo, H \& Hanny, WM, 2014, 'Identifikasi Bakteri Esherichia coli pada Ikan Selar (Selaroides sp.) Bakar di Beberapa Resto di Kota Manado', vol.2, no.1, hal.10-13

Nugroho, A, 2006, Bioindikator Kualitas Air, Cetakan 1, Universitas Trisakti, Jakarta 
Nurmawati, F, Mifbakhuddin, SR \& Wardani, 2009, 'Hubungan antara Hygiene perorangan petugas dan sanitasi depo air minum isi ulang dengan jumlah bakteri Coliform di Kelurahan Sendang Mulyo Kota Semarang', Skripsi, Fakultas Kesehatan Masyarakat, Universitas Muhammadiyah, Semarang

Peraturan Manteri Kesehatan, No 492/MENKES / Per/ IV/ 2010, Tentang Persyaratan Kualitas Air Minum, Manteri Kesehatan RI, Jakarta

Prajna, P, Martini, Sri, Y, 2016, Identifikasi Keberadaan Coliform\&Esherichia coli Pada Es Jeruk Kemasan (Studi Wilayah Sekolah Dasar Kecamatan Tembalang Kota Semarang),Jurnal Kesehatan Masyarakat, Vol.4, No 4, Hal 439

Razaevie TR, 2009, 'Kontaminasi Bakteri Esherichia coli pada Produk Depot AirMinum di Kecamatan Pancoran Mas Depok', Skripsi, Depok, Universitas Indonesia

Slamet, J.S., 2009, Kesehatan Lingkungan, Gajah Mada University Press; Yogyakarta

Soemirat, 2002,'Kesehatan Lingkungan', Cetakan ke-5, Gadjah MadaUniversity Press, Yogyakarta

Supardi, 1999, Mikrobiologi dalam Pengolahan dan Keamanan Pangan, Bandung

SNI. 2009. SNI 7388 : 2009, Batas Maksimum Cemaran Mikroba Dalam Pangan, Badan Standarisasi Nasional;Jakarta

Tururaja, T dan Mogea R, 2010, Bakteri Coliform di Perairan Teluk Doreri, Monokwari Aspek Pencemaran Laut dan Identifikasi Spesies,Jurnal Universitas Negeri Papua,vol. 15 no 1 hal 47-52

Waluyo,L, 2008, Teknik Dan Metode Dasar Dalam Mikorobiologi, Universitas Muhammadiyah Malang Press, Malang

Widiyanti NLPM, Ristiati NP, 2004, 'Analisis Kualitatif Bakteri Koliform pada Depo Air Minum Isi Ulang di Kota Singaraja Bali',Jurnal EkologiKesehatan, Vol 3 No 1 hal : 64-73 